Journal of Telenursing (JOTING)

Volume 1, Nomor 2, Desember 2019

e-ISSN: 2684-8988

p-ISSN: 2684-8996

DOI: https://doi.org/10.31539/joting.v1i2.909

\title{
PENGARUH PHOTOVOICE INTERACTIVE TERHADAP PENINGKATAN PENGETAHUAN PENANGANAN BENCANA LONGSOR PADA REMAJA
}

\author{
Evi Supriatun ${ }^{1}$, Uswatun Insani ${ }^{2}$, Ariani Indrastuti ${ }^{3}$ \\ Sekolah Tinggi Ilmu Kesehatan Bhakti Mandala Husada Slawi ${ }^{1,2,3}$ \\ evisupriatun@gmail.com ${ }^{1}$
}

\begin{abstract}
ABSTRAK
Tujuan dari penelitian ini yaitu untuk mengetahui pengaruh photovoice interactive terhadap pengetahuan penanganan bencana longsor pada remaja. Penelitian ini menggunakan quasi experimental pre test dan post test. Hasil uji $\mathrm{t}$ menunjukkan ada peningkatan pengetahuan penanganan bencana tanah longsor pada remajadibandingkan dengan kelompok kontrol $(p$ value $=0,000)$. Simpulan, photovoice interactive berpengaruh terhadap pengetahuan penanganan bencana tanah longsor pada kelompok usia remaja di Kecamatan Salem Kabupaten Brebes.
\end{abstract}

Kata Kunci: Bencana Longsor, Photovoice Interactive, Remaja

\section{ABSTRACT}

The purpose of this study is to determine the effect of interactive photovoice on landslide disaster management knowledge in adolescents. This study uses a quasi experimental pre test and post test. T test results showed an increase in knowledge of landslide disaster management in adolescents compared with the control group ( $p$ value $=0,000)$. In conclusion, Photovoice interactive influences the knowledge of landslide disaster management in adolescent age groups in Salem District, Brebes Regency.

Keywords: Landslide Disaster, Photovoice Interactive, Youth

\section{PENDAHULUAN}

Banyaknya daerah yang rawan bencana menjadi salah satu penyebab terjadinya bencana longsor. Beberapa daerah Indonesia yang secara geografis berbentuk pegunungan dan perbukitan merupakan daerah berisiko terjadinya bencana longsor. Selain itu, adanya curah hujan yang tinggi memperkuat faktor risiko terjadinya bencana longsor pada daerah-daerah dengan tingkat kemiringan yang melebihi 30 sampai 40 derajat. Kondisi geografis berupa pegunungan atau perbukitan tersebut tersebar di seluruh wilayah Indonesia sekitar $45 \%$ termasuk daerah yang beriko terjadi erosi dan bencana longsor (Rosita et al., 2018).

Bencana longsor merupakan salah satu bencana yang mengakibatkan adanya korban jiwa, kerusakan lingkungan dan pengaruh terhadap psikologis masyarakat sekitar (Suprayitno \& Soemitro, 2019). Dampak terjadinya bencana longsor terhadap kondisi fisik manusia diantaranya menyebakan trauma fisik, kecacatan dan kematian. Adapun dampak bencana longsor terhadap kerusakan lingkungan meliputi kerusakan rumah, fasilitas pelayanan kesehatan, fasilitas umum, jalan dan lahan pertanian dan lainlain (Isa, 2016). Tahap selanjutnya, bencana longsor berpengaruh terhadap status 
kesehatan dan kesejahteraan masyarakat karena kurangnya sumber daya yang semakin terbatas akibat terjadinya bencana longsor (Aftrinanto et al., 2018).

Berdasarkan data dari United Nation Office for Disaster Risk Reduction (UNDRR) tahun 2018 menjelaskan bahwa bencana alam yang terjadi dunia antara 1998 sampai dengan 2017 sebanyak 7.255 kejadian. Adapun bencana longsor terjadi sebanyak 378 kejadian. Hal tersebut menyebabkan 18.414 jiwa meninggal dunia akibat bencana longsor dan 4,8 juta jiwa mengalami dampak dari terjadinya bencana longsor. Badan Nasional Penanggulangan Bencana (BNPB) tahun 2019 menjabarkan data kejadian bencana alam di Indonesia dari bulan Januari sampai Februari 2019 sebanyak 283 bencana alam. Bencana longsor terjadi sebanyak 68 kejadian, dengan jumlah korban yang meninggal dan hilang sebanyak 10 jiwa, korban yang menderita dan mengungsi sebanyak 701 jiwa dan menyebabkan kerusakan rumah sebanyak 169 bangunan. Menurut Data Informasi Bencana Indonesia (DIBI) tahun 2019, menjelaskan bahwa Provinsi Jawa Tengah menempati urutan pertama yang mengalami kejadian bencana alam tertinggi di Indonesia yaitu sebanyak 596 kejadian.

Berbagai bencana alam terjadi di daerah-daerah Provinsi Jawa Tengah. Berdasarkan hasil penelitian yang dilakukan oleh Safitri et al., (2017) menjelaskan bahwa terdapat Kabupaten Brebes termasuk dalam kelompok daerah yang sering mengalami bencana alam, dengan bencana longsor yang paling sering terjadi sebanyak 55 kejadian. Badan penanganan bencana daerah (2019) menjelaskan bahwa Kecamatan Salem Kabupaten Brebes mengalami bencana longsor pada bulan Februari 2019. Desa yang mengalami bencana longsor yaitu Desa Pasir Panjang yang mengakibatkan 5 korban jiwa, 14 orang hilang dan 5 orang mengalami cedera fisik. Bencana longsor tersebut mengakibatkan adanya kerusakan pada daerah persawahan, bangunan dan akses jalan yang terputus.

Penyebab terjadinya bencana longsor dibagi menjadi 2 (aspek) yaitu faktor alam dan faktor tindakan yang dilakukan oleh manusia. Faktor alam diantaraya kondisi geografis yang curam atau kemiringan daerah perbukitan, kondisi batuan kapur yang rawan longsor dan cuaca seperti hujan yang tidak menentu. Penyebab bencana longsor yang diakibatkan oleh tindakan yang dilakukan oleh manusia dapat berupa adanya penggunaan atau tata lahan hijau yang disalahgunakan untuk pertanian atau persawahan sehingga tidak ada resapan air saat hujan. Selain itu, pemilihan jenis pohon yang kurang tepat sehingga akar tidak mampu menahan tanah saat terdapat pergerakan tanah mengakibatkan mudahnya terjadi erosi dan bencana longsor (Surastuti \& Priyono, 2016).

Sebagian besar masyarakat belum memahami tentang hal-hal yang dapat menyebabkan bencana longsor dan upaya penanganan yang harus dilakukan ketika bencana longsor terjadi di daerahnya. Hal tersebut menyebabkan masyarakat belum mampu melakukan penanganan segera yang tepat ketika terdapat anggota masyarakat lainnya yang mengalami cedera fisik saat bencana longsor terjadi (Emaliyawati et al., 2016). Selain itu, kondisi bencana longsor juga menyebabkan kondisi yang stress bagi masyarakat karena faktor kehilangan keluarga, rusaknya bangunan rumah dan lingkungan sekitarnya (Anam et al., 2019). Kondisi tersebut disebabkan kurangnya pengetahuan masyarakat tentang penanganan bencana longsor.

Peran perawat sebagai salah satu petugas pelayanan kesehatan sangat diperlukan untuk meningkatkan pengetahuan masyarakat tentang bencana longsor. Hal yang dapat dilakukan diantaranya melakukan edukasi kesehatan tentang pencegahan dan penanganan pasca bencana longsor. Upaya promotif terkait peningkatan pengetahuan 
penanganan bencana longsor memerlukan sasaran edukasi yang mampu berpartisipasi dan menggerakkan anggota masyarakat lainnya untuk memahami penanganan bencana longsor (Ardia et al., 2015).

Kelompok remaja merupakan bagian dari masyarakat yang memerlukan pengetahuan tentang penanganan bencana longsor. Hal tersebut dikarenakan informasi yang sering didapatkan remaja dalam setting sekolah masih sangat sedikit. Informasi tentang penanganan bencana longsor yang bersumber dari mata pelajaran kurang menjelaskan secara mendalam tentang penanganan yang tepat (Wakhid et al., 2019). Berkaitan dengan hal tersebut, remaja perlu diberikan informasi tentang penanganan bencana longsor karena remaja merupakan kelompok yang berpotensi untuk berpartisipasi dalam upaya pencegahan dan penanganan pasca bencana longsor. Remaja memiliki kemampuan untuk memahami informasi dan mensosialisasikan pada anggota masyarakat lainnya baik secara komunikasi langsung ataupun menyampaikan pada kegiatan-kegiatan yang biasa dilakukan remaja di sekolah ataupun di masyarakat (Wahyudi \& Hariyanto, 2018).

Photovoice merupakan metode yang mengutamakan partisipasi peserta edukasi kesehatan berbasis komunitas dimana peserta dapat menyampaikan pengalamannya terkait kejadian yang dialami di daerahnya dengan menggunakan media foto. Metode photovoice membantu mengkomunikasikan aktivitas fisik yang biasa dilakukan masyarakat, dan kemitraan yang diselenggarakan di masyarakat tersebut (Hamilton et al., 2017). Photovoice memberikan manfaat berupa pengalaman yang kuat terhadap kejadian yang dialami oleh masyarakat dan memberikan wawasan suatu pemahaman yang dapat meningkatkan pengetahuan masyarakat (Komaie et al., 2018).

Penggunaan photovoice dalam peningkatan pengetahuan remaja di Indonesia telah diaplikasikan dalam beberapa hal. Saputra (2017) menerapkan photovoice untuk meningkatkan perilaku prososial pada remaja terhadap penanganan kejadian bullying dan menumbuhkan empati di lingkungan sekolah. Maryanti et al., (2016) juga menggunakan metode photovoice untuk membantu responden dalam mendeskripsikan kesehatan seksual dan reproduksi serta peranan fasilitas kesehatan di lingkungan pekerja seksual.

\section{METODE PENELITIAN}

Penelitian ini menggunakan desain kuantitaf dengan desain quasi experimental pre post test with control group. Intervensi pada penelitian ini berfokus pada edukasi kesehatan dengan menggunakan metode photovoice interactive terkait penanganan bencana tanah longsor. Perbedaan antara kelompok intervensi dan kontrol yaitu pada kelompok intervensi metode edukasi kesehatan menggunakan photovoice interactive, sedangkan pada kelompok kontrol hanya diberikan leaflet penanganan bencana tanah longsor. Tahap awal perlakuan pada penelitian ini yaitu dilakukan pre test, baik pada kelompok intervensi maupun kelompok kontrol. Tahap berikutnya yaitu pemberian perlakuan pada masing-masing kelompok. Tahap akhir dari perlakuan penelitian yaitu dilakukan post test pada kelompok intervensi dan kontrol.

Populasi pada penelitian ini adalah seluruh siswa SMK di Kabupaten Brebes Kecamatan yaitu SMK Al-Azhar, SMKS Islam Al Amanah, dan SMKS Izzul Islam Salem. Berdasarkan penghitungan sampel, sampel yang dibutuhkan pada kelompok intervensi sebanyak 48 responden. Teknik pengambilan sampel pada penelitian ini dimulai dengan menentukan wilayah penelitian dengan menggunakan cluster sampling dengan mempertimbangkan lokasi terdekat dengan daerah bencana longsor di Desa 
Pasir Panjang Kecamatan Salem Kabupaten Brebes.Penelitian ini dilakukan di SMKS Islam Al Amanah (kelompok kontrol) dan SMK Al-Izzul Islam (kelompok intervensi) selama 4 minggu.

Alat pengumpulan data pada penelitian ini menggunakan kuesioner A dan B. Kuesioner A berisi data demografi responden yaitu jenis kelamin dan tingkat pendidikan orang tua. Kuesioner B merupakan kuesioner pengetahuan penanganan bencana tanah longsor yang berjumlah 15 pertanyaan.

\section{HASIL PENELITIAN}

Hasil Analisis Univariat

Karakteristik Responden

Tabel. 1

Distribusi Karakteristik Responden Berdasarkan Jenis Kelamin dan Tingkat Pendidikan Orang Tua $(n=48)$

\begin{tabular}{lcc}
\hline \multicolumn{1}{c}{ Karakteristik } & Frekuensi & Persentase \\
\hline Jenis Kelamin & & \\
1. Laki-laki & 24 & 50 \\
2. Perempuan & 24 & 50 \\
\hline Tingkat Pendidikan Orang Tua & & \\
0. Tidak Sekolah & 0 & 0 \\
1. SD & 32 & 66,7 \\
2. SMP & 13 & 27,1 \\
3. SMA & 3 & 6,3 \\
4. PT & 0 & 0 \\
\hline
\end{tabular}

Berdasarkan tabel 1 proporsi jenis kelamin laki-laki dengan perempuan pada penelitian ini memiliki persentase yang sama. Hal tersebut disebabkan latar belakang pendidikan responden yang berasal dari Sekolah Menengah Kejuruan dengan adanya sebaran jenis kelamin laki-laki dan perempuan yang merata. Adapun tingkat pendidikan orang tua responden didominasi pendidikan SD dan SMP. Hal tersebut sesuai dengan kondisi fasilitas pendidikan yang jarang di daerah rawan bencana longsor tersebut. Akses jalan yang sempit serta transportasi yang kurang dan jarak yang sangat jauh dengan tempat tinggal masyarakat di daerah tersebut menjadi salah satu faktor rendahnya tingkat pendidikan masyarakat tersebut.

\section{Pengetahuan Penanganan Bencana Tanah Longsor}

Tabel. 2

Distribusi Rerata Pengetahuan Responden tentang Penanganan Bencana Tanah Longsor $(n=96)$

\begin{tabular}{lllll}
\hline \multicolumn{1}{c}{ Pengetahuan } & Kelompok & N & Mean & SD \\
\hline Sebelum & Intervensi & 48 & 11,71 & 1,237 \\
& Kontrol & 48 & 12,02 & 1,345 \\
\hline Sesudah & Intervensi & 48 & 13,88 & 0,815 \\
& Kontrol & 48 & 12,96 & 1,414 \\
\hline
\end{tabular}

Berdasarkan tabel 2 menunjukkan bahwa rerata pengetahuan responden sebelum intervensi pada kelompok intervensi dengan kelompok kontrol berbeda. Rerata pengetahuan kelompok intervensi lebih rendah daripada kelompok kontrol. Hal ini 
disebabkan fasilitas dan akses informasi terkait penanganan bencana tanah longsor di wilayah kelompok intervensi yang lebih sedikit dibandingkan kelompok kontrol. Akan tetapi setelah diberikan intervensi photovoice interactive, rerata pengetahuan kelompok intervensi lebih tinggi daripada kelompok kontrol.

\section{Hasil Analisis Bivariat}

Analisis bivariat menjelaskan tentang pengaruh variabel independen yaitu photovoice interactive terhadap variabel dependen yaitu perilaku pengetahuan penanganan bencana tanah longsor. Analisis bivariat dilakukan setelah dilakukan uji normalitas dan uji homogenitas.

\section{Perubahan Pengetahuan Penanganan Bencana Tanah Longsor}

Analisis skor pengetahuan penanganan bencana tanah longsor antara sebelum dan sesudah dilakukan perlakuan photovoive interactive dapat diketahui pada tabel berikut ini:

Tabel. 3

Analisis Perubahan Skor Pengetahuan Sebelum dan Sesudah Perlakuan pada Kelompok Intervensi dan Kontrol $(n=96)$

\begin{tabular}{|c|c|c|c|c|c|c|c|c|}
\hline \multirow{3}{*}{ Variabel } & \multicolumn{4}{|c|}{ Kelompok Intervensi } & \multicolumn{4}{|c|}{ Kelompok Kontrol } \\
\hline & Sebelum & Sesudah & & & Sebelum & Sesudah & & \\
\hline & $\begin{array}{l}\text { Mean } \\
\text { (SD) }\end{array}$ & $\begin{array}{l}\text { Mean } \\
\text { (SD) }\end{array}$ & Selisih & $\begin{array}{c}p \\
\text { value }\end{array}$ & $\begin{array}{l}\text { Mean } \\
\text { (SD) }\end{array}$ & $\begin{array}{l}\text { Mean } \\
\text { (SD) }\end{array}$ & Selisih & $\begin{array}{c}p \\
\text { value }\end{array}$ \\
\hline Pengetahuan & $\begin{array}{c}11,71 \\
(1,237)\end{array}$ & $\begin{array}{c}13,88 \\
(0,815)\end{array}$ & 2,17 & 0,000 & $\begin{array}{c}12,02 \\
(1,345)\end{array}$ & $\begin{array}{c}12,96 \\
(1,414)\end{array}$ & 0,94 & 0,000 \\
\hline
\end{tabular}

Berdasarkan tabel 3 menunjukkan bahwa terjadi peningkatan skor pengetahuan penanganan bencana tanah longsor. Hasil peningkatan pengetahuan pada kelompok intervensi yang diberikan photovoice interactive menunjukkan peningkatan yang lebih tinggi dibandingkan kelompok kontrol.

\section{Perbedaan Pengetahuan antara Kelompok Intervensi dan Kontrol}

Analisis bivariat untuk mengetahui perbedaan pengetahuan antara kedua kelompok dijelaskan sebagai berikut:

Tabel. 4

Analisis Perbedaan Pengetahuan Responden antara

Kelompok Intervensi dan Kontrol $(n=96)$

\begin{tabular}{|c|c|c|c|c|c|}
\hline \multirow{2}{*}{ Variabel } & \multicolumn{2}{|c|}{ Intervensi } & \multicolumn{2}{|c|}{ Kontrol } & \multirow{2}{*}{$\mathrm{p}$ value } \\
\hline & Mean & SD & Mean & SD & \\
\hline Pengetahuan & 13,88 & 0,816 & 12,96 & 3,707 & $0,000^{*}$ \\
\hline
\end{tabular}

Berdasarkan tabel 4 menunjukkan bahwa ada perbedaan pengetahuan yang signifikan antara kelompok intervensi dengan kelompok kontrol. 


\section{PEMBAHASAN}

\section{Karakteristik Responden Jenis Kelamin}

Hasil analisis univariat pada variabel usia mendeskripsikan persentase laki-laki dan perempuan seimbang. Persentase jenis kelamin yang besarnya seimbang disebabkan ketika pengambilan sampel jumlah laki-laki dan perempuan hampir sama. Hal ini sejalan dengan penelitian yang dilakukan oleh Suhariyati et al., (2016) yang sama persentase jenis kelamin baik laki-laki maupun perempuan sama.

\section{Tingkat Pendidikan Orang Tua}

Berdasarkan data hasil penelitian, sebagian besar pendidikan orang tua responden adalah sekolah dasar dan sekolah menengah pertama. Hal tersebut dikarenakan kondisi geografis lingkungan yang dikelilingi oleh perbukitan dan jalan yang sangat curam dan jauh untuk mengakses fasilitas pendidikan. Kurangnya lapangan pekerjaan yang tersedia di sekitar tempat tinggalnya dianggapkurang linear dengan pendidikan yang ditempuh menyebabkan masyarakat masih memiliki minat yang rendah terhadap pendidikan. Namun hal tersebut berdampak terhadap kesadaran masyarakatterhadap perilaku yang dapat menyebabkan bencana tanah longsor di daerahnya. Maryanti et al., (2017) menjelaskan bahwa pendidikan mempengaruhi kesiagaan terhadap bencana alam yang terjadi. Pendidikan menengah ke atas memiliki kesiapsiagaan yang lebih baik dibandingkan pendidikan yang rendah.

\section{Pengaruh Photovoice terhadap Pengetahuan Penanganan Bencana Longsor}

Pengetahuan terkait penanganan bencana tanah longsor dipengaruhi oleh metode photovoice interactive sebesar $15,3 \%$. Hal ini disebabkan melalui metode photovoice interactive, remaja mempelajari suatu materi dengan beberapa tahapan dimulai dari pengenalan, berdiskusi, mengamati lingkungan sekitar, refleksi dan menampilakan foto yang dapat mengilustrasikan hal yang terjadi saat terjadi bencana tanah longsor dan penanganan yang dilakukan serta hal-hal yang dapat dicegah agar tidak terjadi bencana tanah longsor. Proses yang dilakukan secara bertahap memberikan pemahaman yang lebih dalam dan luas pada remaja tentang bencana tanah longsor.

Saputra (2017) menjelaskan bahwa salah satu program promosi kesehatan yang dilakukan di sekolah dilakukan dengan mengenalkan tentang perilaku yang tepat pada lingkungan sosial dengan meningkatkan kesadaran remaja. Intervensi yang dilakukan pada penelitian tersebut menggunakan metode photovoice. Hasil penelitian tersebut memaparkan bahwa perilaku remaja meningkat secara signifikan setelah diberikan edukasi dengan metode photovoice. Pada penelitian tersebut, peneliti menjelaskan penggunaan foto untuk mengungkapkan tentang hal yang difikirkan oleh remaja tentang lingkungannya yang mendukung ke arah perilaku yang positif. Selain itu, photovoice juga membantu mengeksplorasi perasaan remaja dan memberikan kesadaran terhadap perilaku yang harus dilakukan saat kondisi yang tidak menyenangkan.

Penelitian ini mengukur variable pengetahuan hanya melalui pre test dan post test, yang mendeskripsikan terjadi peningkatan skor pengetahuan penanganan bencana tanah longsor pada kelompok usia remaja. Hal ini sejalan dengan penelitian yang dilakukan oleh Gonzalez (2019) menjabarkan intervensi photovoice yang dapat dilakukan pada remajauntuk meningkatkan pemberdayaan pada remaja, dengan evaluasi pre test sebelum intervensi dan post test sebagai evaluasi akhir. 
Prasetyo \& Hayati (2019) menjelaskan bahwa peningkatan pengetahuan tentang penanganan bencana alam penting dilakukan untuk menstimulasi remaja untuk berperan aktif serta tanggap saat bencana tersebut terjadi di lingkungan sekitarnya. Murtaqib \& Widayati (2017) menambahkan bahwa kelompok remaja merupakan sasaran edukasi yang tepat karena memiliki mampu memberikan informasi secara lengkap pada lingkungan sekitarnya, terutama keluarga dan teman sekelompok usianya. Selain itu, adanya pengetahuan tentang bencana meningkatkan sikap remaja tentang kesiapsiagaan terhadap bencana yang terjadi melalui tanda-tanda alam yang dapat diamati.

Berdasarkan situasi tersebut, remaja mampu merasakan hal-hal yang terjadi dalam photovoice interactive baik yang menyenangkan atau merugikan untuk kesehatannya. Remaja juga belajar berpendapat dan mendengarkan pendapat yang dikemukakan oleh teman sebanyanya. Upaya tersebut merupakan proses yang kompleks, dimulai dari mengenali masalah, kemampuan diri atau self efficacy kemudian mempertimbangkan setiap hambatan yang merugikan dan hal-hal yang menguntungkan untuk meningkatkan kesehatannya. Potter \& Perry (2013) menjelaskan bahwa remaja telah mengalami peningkatan pertumbuhan dan perkembangan. Hal yang dominan menonjol dari perkembangan remaja diantaranya secara kognitif mampu berpikir kritis. Adapun perkembangan sosial, remaja mampu menempatkan diri sebagai bagian dari kelompok, baik pada posisi pemimpin ataupun anggota yang selalu berupaya mematuhi aturan atau norma yang berlaku di dalamnya.

Penelitian ini menggunakan photovoice interactive dengan mengenalkan pada remaja terkait penanganan bencana longsor diawali dengan sesi diskusi. Kegiatan diskusi memfasilitasi remaja memahami permasalahan tentang bencana yang sering tidak disadari masyarakat dan dampak dari bencana tanah longsor. Remaja memaksimalkan penggunaan photovoice untuk merefleksikan perilaku masyarakat yang berisiko terjadinya bencana longsor.

Remaja menyampaikan terdapat bebapa perilaku masyarakat yang dapat diamati yang dapat menyebabkan resiko tinggi terjadinya bencana longsor di daerahnya yang tergolong pegunungan yang curam. Perilaku tersebut diantaranya penggunaan daerah lereng yang ditanami tanaman palawija seperti jagung. Menurut remaja, pada daerah tersebut sebaiknya tanaman yang ditanam adalah pohon dengan jenis kayu yang memiliki akar yang cukup kuat sehingga dapat menahan air saat hujan deras. Pendapat tersebut menunjukkan bahwa remaja mampu mengamati dan berpikir kritis dari penyebab terjadinya bencana longsor. Berikut gambar yang menjadi fokus responden penelitian yang merefleksikan perilaku yang tidak sesuai dengan pencegahan bencana tanah longsor.

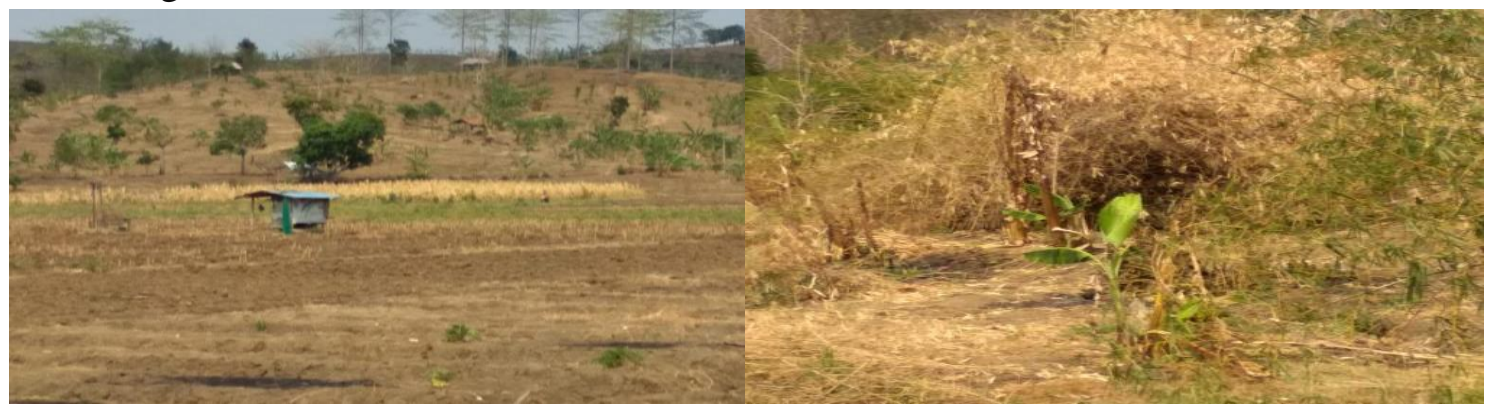

Gambar. 1

Penyebab Bencana Longsor 
Remaja juga mampu mengungkapkan bahwa adanya kerusakan yang diakibatkan dari bencana tanah longsor diantaranya adanya jalan akses jalan yang terputus. Keadaan tersebut beberapa kali terjadi, terutama saat hujan deras sehingga masyarakat harus memilih jalan alternatif lain untuk mencapai lokasi tujuan. Selain itu, remaja mengungkapkan adanya kerusakan bangunan dan rumah akibat bencana tanah longsor.

Berikut gambar yang menjadi fokus remaja merefleksikan akibat dari bencana tanah longsor di daerahnya.

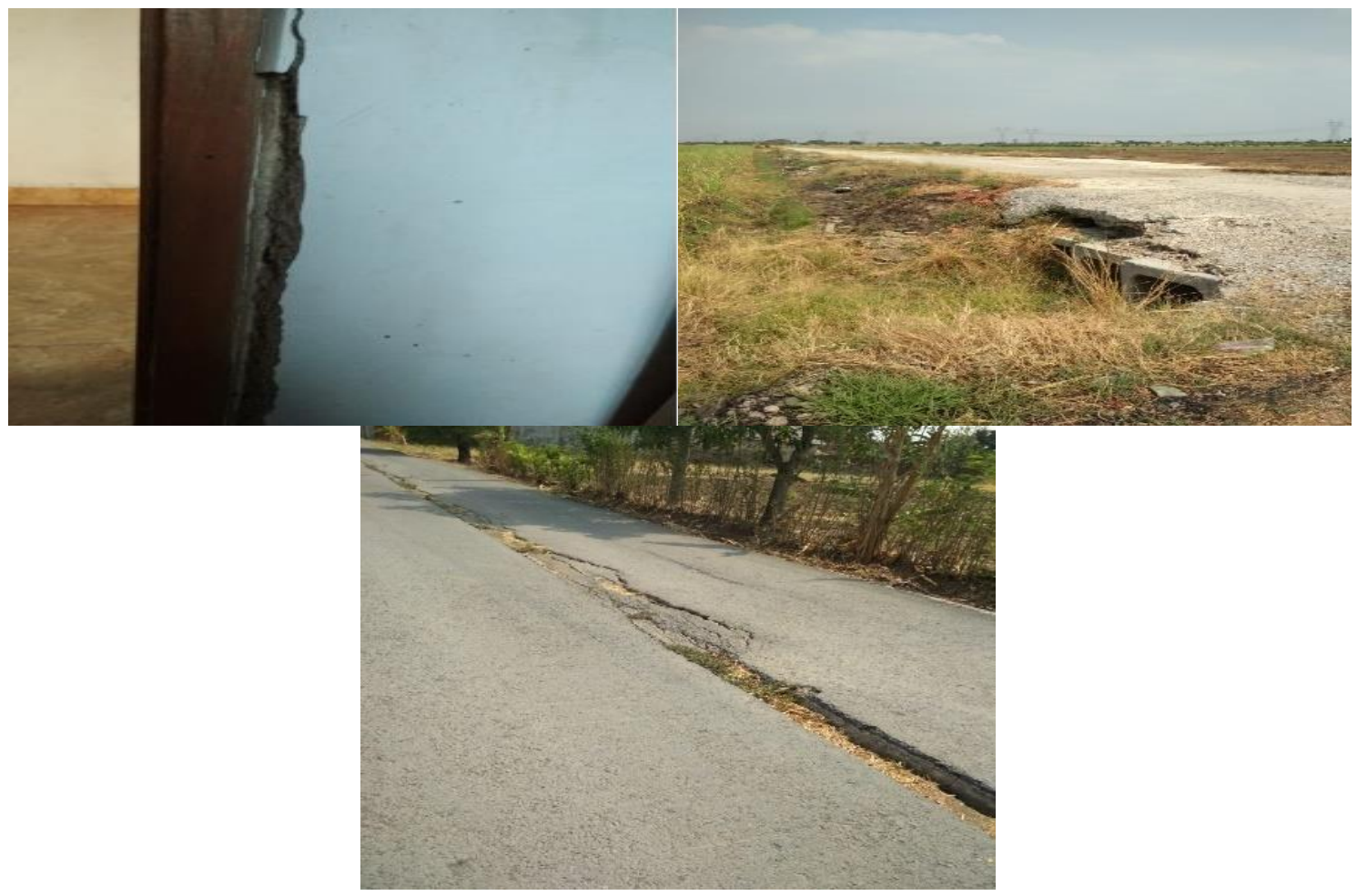

Gambar. 2

Akibat Bencana Longsor

Peningkatan kesehatan remaja dapat dimulai dengan perubahan perilaku dengan memanfaatkan sekolah sebagai setting yang menyediakan informasi kesehatan terkait dengan kesehatan fisik dan lingkungan (Avery et al., 2013). Remaja merupakan bagian dari sub sistem dari masyarakat yang perlu mendapatkan edukasi tentang penanganan bencana alam (Romdhonah et al., 2019). Hal ini disebabkan remaja merupakan bagian dari masyarakat yang memiliki kemampuan untuk mempengaruhi anggota masyarakat lainnya dalam berperilaku yang tepat.

Penelitian ini termasuk dalam Community-Based Participatory Research (CBPR) atau pendekatan penelitian dengan partisipatif berbasis masyarakat melalui metode photovoice. CBPR membantu meningkatkan pengetahuan masyarakat yang rentan terhadap bencana dan mengembangkan secara kontekstual strategi penanganan bencara melalui dialog visual dan diskusi dapat meningkatkan kesadaran masyarakat terhadap bencana. Pendekatan CBPR menyatukan pengetahuan dan ide-ide dari masyarakat dan sekitarnya, menghasilkan kapasitas melalui peningkatan kesadaran masyarakat, pengembangan keterampilan dan sistem berkelanjutan terhadap bencana (Crabtree \& Braun, 2015). 
Menurut Schuman \& Binder (2018) metode photovoice sangat efektif degunakan dengan melibatkan partisipatif dari partisipan dan berkontribusi yang baik untuk penelitian bencana. Metode photovoice adalah metode inovatif untuk menangkap pemahaman dan meningkatkan pengetahuan masyarakat tentang konteks bahaya dan bencana untuk memberikan wawasan teoritis yang kaya terkait peristiwa ekstrem yang secara intrinsik bersifat geografis dan berbasis tempat. Penggunaan metode photovoice untuk memperoleh pengetahuan mengenai persepsi anggota masyarakat tentang dampak jangka panjang pada kualitas hidup mereka ketika bencana mematikan menghantam wilayahnya. Secara keseluruhan, peserta memotret lebih banyak gambar negatif daripada positif (Anang \& Wilson, 2016).

Menurut penelitian Terris \& Hedlund (2019) photovoice sangat berguna untuk meningkatkan pengetahuan dan mengevaluasi wawasan masyarakat tentang bencana. Responden menikmati metode belajar dari diskusi metode ini. Dengan berbagi gambar memberi peserta kepercayaan diri untuk dapat berdiskusi tentang masalah dengan menggunakan gambar sebagai panduan. Dengan metode diskusi berulang, memungkinkan untuk refleksi dan memfasilitasi atau memberi kesempatan peserta untuk membangun mengekspolorasi persepsi tentang resiko bencana.

\section{SIMPULAN}

Simpulan penelitian adalah photovoice interactive berpengaruh terhadap pengetahuan penanganan bencana tanah longsor pada kelompok usia remaja di Kecamatan Salem Kabupaten Brebes. Berikut ini diuraikan kesimpulan dari penelitian ini:

Responden penelitian ini memiliki karakteristik kelompok remaja pada rentang usia 15 sampai 18 tahun, proporsi jenis kelamin laki-laki dan perempuan yang seimbang, sebagian kecil memiliki pengalaman mengalami bencana tanah longsor dan didominasi tingkat pendidikan orang tua responden berpendidikan Sekolah Dasar dan Sekolah Menengah Pertama.

Peningkatan pengetahuan pada kelompok intervensi lebih baik dibandingkan kelompok kontrol, setelah diberikan intervensi photovoice interactive. Intervensi photovoice interactive sesuai diterapkan pada kelompok usia remaja. Hal ini ditunjukkan dengan peningkatan pengetahuan dan sikap penanganan bencana tanah longsor pada kelompok intervensi lebih tinggi daripada kelompok kontrol.

Adanya perbedaan yang signifikan pada rerata pengetahuan penanganan bencana tanah longsor pada kelompok intervensi setelah diberikan edukasi kesehatan dengan metode photovoice interactive. Hal ini menunjukkan bahwa metode photovoice interactive merupakan salah satu metode inovatif yang dapat digunakan dalam edukasi kesehatan yang efektif untuk meningkatkan pengetahuan dan sikap pada kelompok usia remaja.

\section{SARAN}

Photovoice interactive direkomendasikan sebagai salah satu metode dalam edukasi kesehatan pada kelompok remaja 


\section{DAFTAR PUSTAKA}

Aftrinanto, Z., Hayati, E. N. N., \& Urbayatun, S. (2018). Spiritual Emotional Freedom Technique (SEFT) untuk Meningkatkan Kualitas Hidup pada Wanita yang Mengalami Bencana Tanah Longsor. Jurnal Studia Insania, 6(1), 069-089

Anam, C., Sholichah, M., \& Kushartati, S. (2019). Intervensi Psikososial untuk Menurunkan PTSD dan Meningkatkan Resiliensi Warga Penyintas Bencana Tanah Longsor di Banjarnegara. Psikoislamedia: Jurnal Psikologi, 3(1)

Anang, L., \& Wilson, S. (2016). Photovoice: Assessing the Long-Term Impact of a Disaster on a Community's Quality of Life. https://doi.org/10.1177/1049732315576495

Ardia, P., Juwita, R., Risna, R., Alfiandi, R., Arnita, Y., Iqbal, M., \& Ervina, E. (2015). Peran dan Kepemimpinan Perawat dalam Manajemen Bencana pada Fase Tanggap Darurat. Idea Nursing Journal, 6(1), 25-31

Avery, G., Johnson, T., Cousins, M., \& Hamilton, B. (2013). The School Wellness Nurse: A Model for Bridging Gaps in School Wellness Programs. Pediatric Nursing, 39(1), 13-7; quiz 18. Retrieved from https://search.proquest.com/docview/1317918923?accountid=17242

Badan Nasional Penanggulangan Bencana (BNPB). (2019). Info Bencana. Jakarta: Badan Nasional Penanggulangan Bencana. https://bnpb.go.id//publikasi/infobencana

Badan Penanganan Bencana Daerah. (2019). Laporan Bencana. Semarang: Badan Penanganan Bencana Daerah. Provinsi Jawa Tengah. https://bpbd.jatengprov.go.id/category/laporan-bencana/longsor/page/58/

Crabtree, C., \& Braun, K. (2015). PhotoVoice: A Community-Based Participatory Approach in Developing Disaster Reduction Strategies. Progress in Community Health Partnerships: Research, Education, and Action, 9(1), 31-40. http://doi.org/10.1353/cpr.2015.0012

Data Informasi Bencana Indonesia. (DIBI). (2019). Jumlah Kejadian Bencana Alam. Jakarta: Badan Nasional Penanggulangan Bencana. http://dibi.bnpb.go.id/

Emaliyawati, E., Prawesti, A., Yosep, I., \& Ibrahim, K. (2016). Manajemen Mitigasi Bencana dengan Teknologi Informasi di Kabupaten Ciamis. Jurnal Keperawatan Padjadjaran, 4(1)

Gonzalez, M. (2019). Utilizing Photovoice and Youth Advisory Boards: Collaborative Research to Strengthen Adolescent Empowerment. OSR Journal of Student Research, 5(1), 176

Hamilton, K. C., Richardson, M. T., Owens, T., Yerby, L. G., Lucky, F. L., \& Higginbotham, J. C. (2017). Using Photovoice to Identify the Physical Activity Practices of Children Residing in Alabama's Black Belt Region. Journal of Community Practice, 25(3-4), 488-503

Isa, M. (2016). Bencana Alam: Berdampak Positif atau Negatif terhadap Pertumbuhan Ekonomi. The $3^{\text {rd }}$ University Research Colloquium 2016. ISSN 2407-9189. Hal $147-156$

Komaie, G., Gilbert, K. L., Arroyo, C., \& Goodman, M. S. (2018). Photovoice as a Pedagogical Tool to Increase Research Literacy among Community Members. Pedagogy in Health Promotion, 4(2), 108-114

Maryanti, S., Lestari, E., Putri, W., Wardani, A. R., \& Haris, F. (2017). Hubungan Tingkat Pendidikan Masyarakat terhadap Kesiapsiagaan Bencana Tanah Longsor di Kelurahan Giritirto Kecamatan Wonogiri. Prosiding Seminar Nasional 
Geografi UMS 2017. ISBN: 978-602-361-072-3. Hal 255-263

Murtaqib, M., \& Widayati, N. (2017). Pengaruh Pelatihan terhadap Kesiapsiagaan Menghadapi Bencana Banjir pada Siswa di Pondok Pesantren Al Hasan I dan Al Hasan II Panti Jember. Prosiding HEFA (Health Events for All), 288-293

Potter, P. A. \& Perry, A. G. (2013). Fundamental of Nursing. St. Louis, Missouri: Elseiver Inc

Prasetyo, D. N. H., \& Hayati, R. (2019). Peningkatan Pengetahuan Kesiapsiagaan Banjir Pengurus Karang Taruna dengan Metode Diskusi Berbantuan Media Audio Visual di Kelurahan Sawah Besar Tahun 2018. Edu Geography, 7(3), 222-231

Romdhonah, D. L., Sucipto, A., \& Nekada, C. D. Y. (2019). Pengaruh Edukasi Managemen Bencana Gempa Bumi terhadap Kesiapsiagaan Siswa dalam Menghadapi Gempa Bumi. Jurnal Ilkes (Jurnal Ilmu Kesehatan), 10(1), 1-9

Rosita, A., Aryanto, D., Noorainy, F., Slamet, M., \& Permadi, D. (2018). Daerah Rawan Bencana Geologi Gerakan Tanah dalam Arahan Kebijakan Mitigasi Kabupaten Ciamis. Jurnal Planologi Unpas, 5(1), 885-896

Safitri, D., Rahmawati, R., \& Hitasari, O. K. (2017). Fuzzy Subtractive Clustering Berdasarkan Kejadian Bencana Alam pada Kabupaten/Kota di Jawa Tengah. Jurnal Statistika Universitas Muhammadiyah Semarang, 5(2)

Saputra, A. T. T. (2017). Photovoice: Metode untuk Meningkatkan Perilaku Prososial pada Siswa SMP. University of Muhammadiyah Malang

Schumann, R., \& Binder, S. (2018). Unseen Potential: Photovoice Methods in Hazard and Disaster Science. Geo Journal, 84(1), 273-289

Suhariyati, S., Hardiani, R. S., \& Rahmawati, I. (2016). Pengaruh Pendidikan Kesehatan dengan Metode Course Review Horay terhadap Pengetahuan dan Sikap Remaja tentang HIV/AIDS di SMK Darus Sholihin Puger Kabupaten Jember (The Effect of Health Education by Course Review Horay Method on Knowledge and Attitudes of. Pustaka Kesehatan, 4(3), 575-582

Suprayitno, H., \& Soemitro, R. A. A. (2019). Pemikiran Awal tentang Prinsip Tindakan Mitigasi Preventif Resiko Bencana Alam bagi Manajemen Aset Infrastruktur \& Fasilitas. Jurnal Manajemen Aset Infrastruktur \& Fasilitas, 3

Surastuti, Y., \& Priyono, K. D. (2016). Pemanfaatan Sistem Informasi Geografi untuk Analisis Risiko Longsor di Kecamatan Tirtomoyo, Kabupaten Wonogiri. Universitas Muhammadiyah Surakarta

Terris, T., \& Hedlund, H. (2019). Examining the Use of Photovoice to Explore Disaster Risk Perception among Native Hawaiians Living on $\mathrm{O}^{`}$ ahu: A Feasibility Study. Hawai 'I Journal of Health \& Social Welfare, 78(9)

United Nation Office for Disaster Risk Reduction(UNDRR). (2018). Disaster and Statistic. New York: United Nation Office for Disaster Risk Reduction. https://www.preventionweb.net/ knowledgebase/disaster-statistics

Wahyudi, Y., \& Hariyanto, T. (2018). Survey Disaster Preparedness Remaja di Kabupaten Malang. Health Care Media, 3(4), 30-34

Wakhid, A., Wulandari, W., \& Saparwati, M. (2019). Gambaran Karakteristik Kesiapsiagaan Bencana pada Remaja. Jurnal Gawat Darurat, 1(1), 1-6 